\title{
Reflective and appreciative actions that support the building of ethical places and spaces
}

\author{
Ulrika Bergmark $^{\mathrm{a} *}$, Tony Ghaye ${ }^{\mathrm{b}}$ and Eva Alerby ${ }^{\mathrm{a}}$ \\ ${ }^{a}$ Lulea University of Technology, Sweden; ${ }^{b}$ The Institute of Reflective Practice, UK
}

\begin{abstract}
This reflective account discusses the 'creative renderings' that surfaced as a consequence of a workshop about ethical issues in education, with school staff in a municipality in northern Sweden. The paper is part of a longer, ongoing conversation in that community about building and sustaining an ethical place and space called 'school'. The focus for the conversation on this particular day was around every child and every teacher being valued in school. We worked alongside 30 school staff throughout that day with two appreciative activities - the Show-and-Share activity and the Building Blocks activity. During the day we also made field notes of teachers' shared experiences, we analysed their writing on Building Blocks and documented the process with a digital camera. After the workshop we invited teachers to write some reflective notes. In the paper we share our collective reflections on what we felt we learnt. The workshop was guided by the principles of participatory and appreciative action research or PAAR.
\end{abstract}

\section{Introduction}

Creative renderings ... emerge when a group of people discover and share stories of their most positive experiences and best practices. (Cooperrider \& Whitney, 2005, p. 10)

We were gathered in a school in a small town in northern Sweden to think and talk about ethical issues and education. The participants were staff (teachers and principals) who work with children up to the age of 16-years-old. They were all from pre-schools and schools in the same municipality, and were being supported by staff from a local university and from an international social enterprise. This paper is part of a longer, ongoing conversation in that community about building and sustaining an ethical place and space called 'school'. In practice a total of 200 teachers and 1500 pupils are involved in this initiative. One part of this initiative was this

\footnotetext{
*Corresponding author. Luleå University of Technology, Department of Education, 97187 Luleå, Sweden. Email: ulrika.bergmark@1tu.se
} 


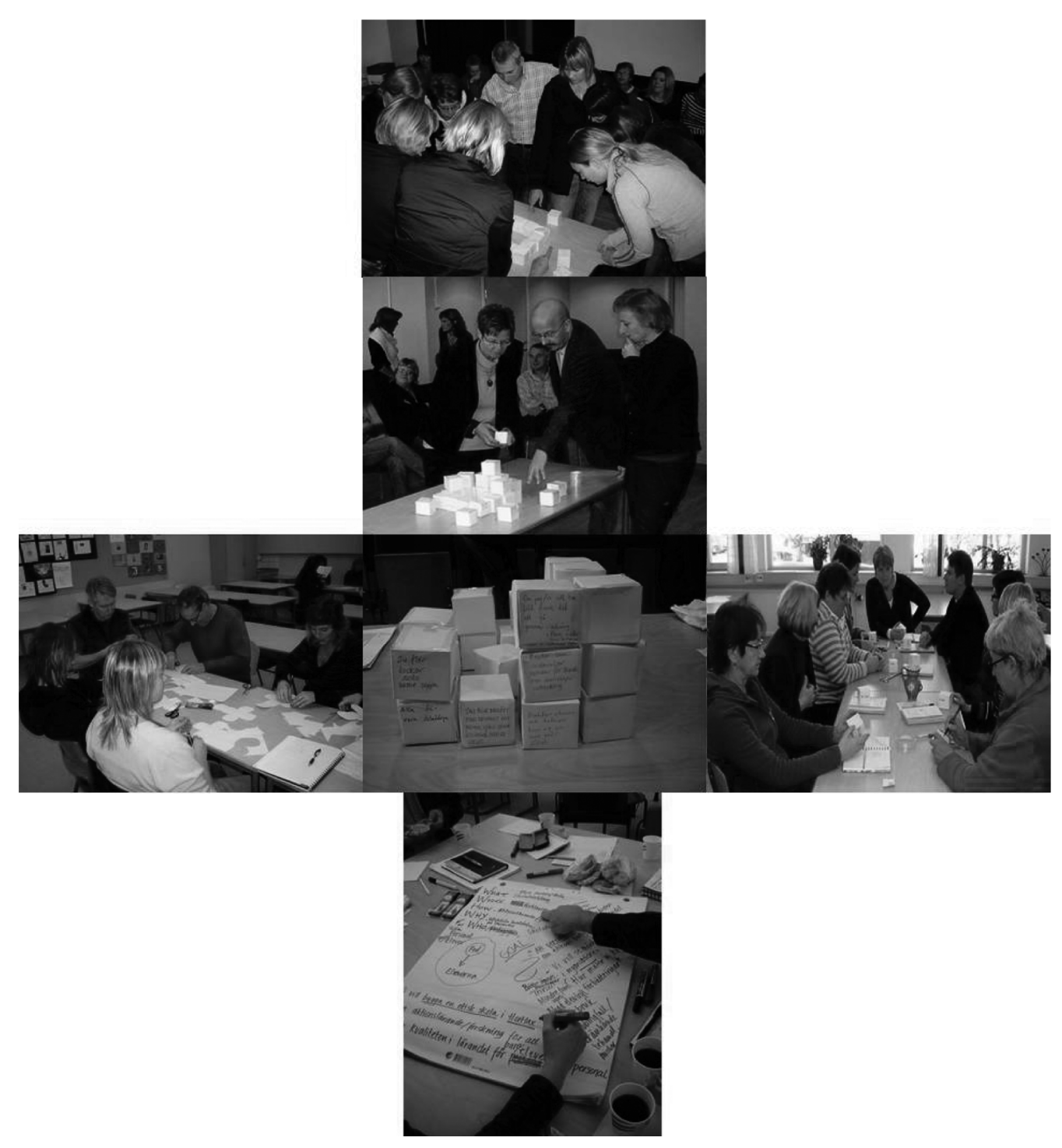

Figure 1. Building of ethical places and spaces

workshop, where 30 of the staff participated. The focus for the conversation on this particular day, and one facilitated by the three of us (Ulrika, Tony and Eva), was around every child and every teacher being valued in school. The aim of this reflective account is to elucidate and discuss the 'creative renderings' that surfaced as a consequence of this day together.

The account makes two assumptions. First, that a characteristic of a place we might wish to regard as an ethical school is one where every child matters. This means, for example, that the education is based on a child's perspective, that children's 
experiences are the starting point in the school and that their voices are taken seriously by the adults. A second characteristic in such a school is that every member of staff matters too. There are hopes and expectations that both teachers and children interact with each other in a respectful way, care about each other and that they grow and develop, both as people and as those working with the best interests of children in mind. Arguably, in an ethical school children and adults share a sense of common community. Another important attribute is learning from each other. This means that both children and staff are open to each other.

We explored the two assumptions mentioned above by inviting staff to respond to the question: 'How would we know that every child mattered in your school?' The invitation to respond to the second assumption was posed as: 'You would know that every member of staff mattered in my school because ...'. Two appreciative activities were developed: a Show-and-Share activity to enhance feelings of positive regard, and a Building Blocks activity that encouraged creativity and the construction of shared understandings. In essence, this account focuses on our reflective learning about applied ethics (or a situated ethics of practice) and appreciative interactions (or relationships of positive regard) and how these may contribute to the building of a place and space for learning that we might wish to call the ethical school. The relational quality of ethical places and spaces is a 'communicative thread' throughout this account. As Buber $(1948,1972)$ suggested, real living begins with relation or within a narrative connection that involves 'us', not just 'me'.

In accordance with Lévinas (1969), we base this paper on the premise that ethics is inherent in every human interaction. Noddings (2002a) emphasizes that ethics is relational and it is about natural caring for the Other. Responsibility for the Other, to use Lévinas' expression, is the basis for this relationship. But we want to stress that responsibility also includes a responsibility for one self, not just the Other. Ethics is also situated, which means that actions are not only motivated by reasons and principles but also based on the needs of the persons involved (Noddings, 1984, 2002b). As Noddings (1984) says, care is at the best a reciprocal act. It is then a relationship between the one-carer and the cared-for, and humans have the ability to both care for and be cared for.

Ethics also involves action. We can come to know a person's ethics by observing them in action. Arguably, individual and collective perspectives on teaching and learning are being transformed by the different ethical encounters experienced each day in our work. Encounters for example about rights-to-autonomy, confidentiality, anonymity, privacy and dignity, vulnerability, openness, scarce resource distribution, professional competence, inter-personal conflicts, injustice, fairness, conflicting loyalties, discipline and encroachments on personal liberty. Some more fundamental questions which influence us are, for example: Why does it matter that we are ethical? What does it mean to be ethical, unethical and who says so? We feel that being ethical is about how we treat each other and, in the context of this particular school initiative, how we best meet the learning needs of children and staff in this place called school. 


\section{The 'sites' of our embedded action}

The public school system in Sweden (for a full explanation see www.skolverket.se) is based on compulsory and non-compulsory schooling and is free. Compulsory schooling (ages 7- to 16-years-old), includes regular compulsory school, school for indigenous Sami pupils, special schools and programmes for pupils with learning disabilities (see Figure 2). The non-compulsory school includes pre-school (ages 1to 5-years-old), and one year of pre-school class (age 6-years-old), and it also includes upper secondary education (ages 16- to 19-years-old), adult education and university education.

All children and young people have the right to equal access to education regardless of gender, where they live, or social or economic factors. The Swedish Government decides and defines the curriculum, national objectives and guidelines for the public education system. Individual municipalities, such as the one in which this participatory work is being undertaken, can determine how its schools are to

\section{The Swedish school system}

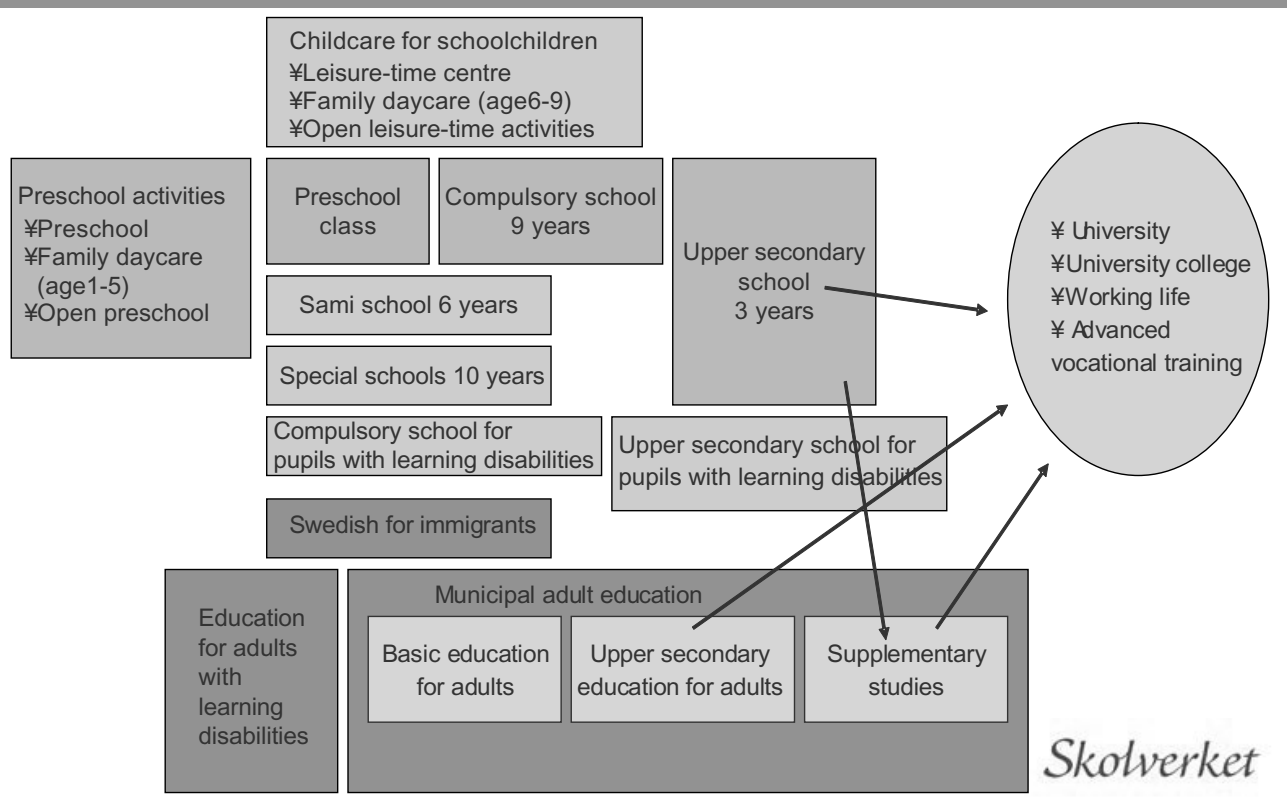

(accessed from www.skolverket.se)

Figure 2. The 'sites' of our embedded action: the Swedish school system 
be run. Principals have the freedom to draw up a local work plan for their particular schools. This is done in consultation with the school's teachers and other personnel. There is a high degree of local responsibility built into the system. The National Agency for Education evaluates and supervises the public school system. Every three years it presents this to the Government. This forms the basis of a national development plan for schools. A teacher's professional work in schools in Sweden has many purposes. For example to help children to develop their learning in particular subjects and also to help children develop an ethical attitude to the world around them. This is clearly stated in the curricula, where it stresses that ethics should pervade all activities in schools (The Ministry of Education, 1994, 1998).

\section{The local school area}

The sites of the reflective and appreciative actions that support the building of the ethical school, are situated within three boxes in Figure 2, namely, pre-school activities, pre-school class and compulsory school. It therefore concerns the quality of the learning experiences for children and young people up to the age of 16-yearsold. The last quality evaluation in this particular school area was completed in 2003 (The Ministry of Education, 2004). The results from this evaluation showed that the schools in general were successful in enhancing the students' learning in different subjects, but work around values and ethics was needed. The activities presented in this paper are part of the school's effort to respond positively to the quality evaluation.

Research results from studies in this school area (Bergmark \& Alerby, 2006) indicate that teachers try to achieve an ethic of care for their children. This is defined as caring about and acknowledging all their children, which means, for example, adjusting to their different needs and personalities. In pursuing an ethic of care, teachers often have to confront the challenge of resolving ethical dilemmas. Our understanding of an ethical dilemma is for example a situation where teachers have to decide between two rights rather than between right and wrong which best describes an ethical conflict. The pragmatic question for teachers is how to work with these dilemmas, and in so doing improve the quality of teaching and learning for children. Building and sustaining an ethic of care is maybe not the easiest way forward, but arguably the hardest way can often be the most creative and encouraging.

\section{Creating a context of appreciation}

We see creating a context of appreciation as a complex long-term culture change challenge. In planning for the day with staff, we tried to work from an understanding of our lived experiences of ethics. As we attempted to create a context for the collective appreciation of the many meanings encapsulated in the phrase, 'ethical places and spaces', different dimensions of it emerged as significant - the importance of asking 
questions, the importance of trust and the importance of open listening and learning from each other. Each one of them influenced the planning for the day.

\section{The importance of asking questions}

Asking questions marks the start of an experienced-based, learning conversation. This has big implications when we think about building an ethical school. If we are unable to talk openly about the complex problems (or challenges) which face us in our work, we get stuck. So what happens next? There are two ways to un-stick a conversation. The first is for one person or group to act unilaterally. To impose on others (no matter how well disguised) their solution to the problem. But is this ethical practice?

There are many kinds of question that we ask and respond to in school. When we ask positive questions we invite positive dialogue and action. In building the ethical school we are pondering on the notion of trying to ask questions that get children and teachers to focus on what is positive and good about school (Bergmark \& Alerby, submitted). Then to follow this up by seeking ways to amplify the positive. If we focus conversations about learning and teaching only on problems, we are simply putting all our energy into trying to get rid of something.

\section{The importance of trust}

Trust is a complex thing to establish and sustain. To us it is essential in building an ethical school. In school communities where shared values, meanings and positive action are so important, trust building is a critical activity. Without trust, conversations of positive regard are non-starters. Reina and Reina (2006) help us understand the importance trust (and betrayal) play in the workplace and how this forms and transforms relationships. At the heart of their book is the notion of transactional trust. This is a process of mutual exchange, reciprocity and something created incrementally over time. In other words we have to give trust in order to increase the likelihood that we will receive it. Reina and Reina (2006) set out three types of transactional trust. They are:

- Contractual trust: This is essentially a trust of character. It is about keeping agreements, honoring intentions and behaving consistently.

- Communication trust: This is essentially a trust of disclosure. It is about a willingness to share information, to tell the truth, admit mistakes, celebrate achievements and successes, maintain confidentiality, give and receive constructive feedback.

- Competence trust: This is essentially a trust of capability. We wondered how capable the participants would be in trusting each other and giving constructive feedback? How capable would we all be in this workshop to provide each other with what we thought was needed in order to continue to better understand, and maybe to improve, our practices? 


\section{The importance of open listening and learning from each other}

Kahane (2004) gives us a sharp reminder of the ways some interactions inside organizations can go. He says:

The root of not listening is knowing. If I already know the truth, why do I need to listen to you? Perhaps out of politeness or guile I should pretend to listen, but what I really need to do is to tell you what I know, and if you don't listen, to tell you again, more forcefully. All authoritarian systems rest on the assumption that the boss can and does know the one right answer. (Kahane, 2004, p. 47)

Communication trust means, as emphasized in the earlier, talking openly and honestly. It brings with it a willingness, and ability on our part, to disclose to Others what's in our head and heart. Listening openly, on the other hand, means being willing and able to positively embrace something different and new from Others. As we interpret Lévinas $(1969,1989)$ he also stresses the importance of openness to Others. This means openness for the Other's abilities and a will to be a part of the relationship and also be a learner. In the following Lévinas (1969) describes his view of learning and education:

It is therefore to receive from the Other beyond the capacity of the I ... this also means: to be taught. The relation with the Other, or Conversation is ... an ethical relation ... this conversation is a teaching [enseignement]. Teaching is not reducible to maieutics; it comes from the exterior and brings me more than I contain. (Lévinas, 1969 , p. 51)

This quotation stresses that when we learn from each other we are in an ethical relation and that we, as individuals, gain more if we stay open and learn from each other through interaction. This isn't as easy as it may sound because it involves issues about such interpersonal relations as power, value alignment and so on.

Wheatley (2002) offers us some useful thoughts in what she eloquently describes as 'seeing how wise we can be together' (p. 28). What we can learn from her work is that, to build an ethical school around conversations of positive regard, we not only have to learn to listen openly, but to listen reflectively. Some of her thoughts are that we need to work out ways to:

- Learn how to acknowledge one another as equals: A language of positive regard, which we suggest is an important part of feeling valued, requires those adults in schools to acknowledge that we are equal as human beings (unequal when in role) and that we need each other.

- Try to stay curious about each other: In staff meetings of various kinds, we need to be genuinely interested in what we have to say to each other, not fearful. This weaves openness together with reflection.

- Help each other listen openly and then act appropriately: It can be hard work to listen. Especially when we are busy and find that our mind is wandering and elsewhere. It's also hard to listen when we feel certain about something. Then we have to help each other to listen openly. 
- Slow down to make time to listen reflectively: If listening is an important part in developing feelings that we matter, so too is slowing down. Often we need to make time to listen to others' views and to reflect on them.

Kahane summarizes his thoughts about reflective listening like this:

To create new realities, we have to listen reflectively. It is not enough to be able to hear clearly the chorus of other voices; we must also hear the contribution of our own voice. It is not enough to be able to see others in the picture of what is going on; we must also see what we ourselves are doing. It is not enough to be observers of the problem situation; we must also recognize ourselves as actors who influence the outcome. (Kahane, 2004, p. 83)

Paulo Freire (1970) calls open listening for 'true dialogue', where both parties speak and both parties listen. Lévinas (1989) argues that openness is a condition for real communication-one has to open oneself for the Other. In this openness the responsibility for the Other reveals itself and here the ability to care can be a helpful way to keep the openness. Noddings (2002b) elaborates further by saying that dialogue draws our attention to the Other, not just to the topic of the conversation. 'Dialogue is central to moral education because it always implies the question: What are you going through?' (2002b, p. 17). Noddings writes about 'moral education' in this quotation, and a question can be-is this valid also for ethical education? According to Colnerud and Granström (2002) the words ethics and morals can be used synonymously. The dialogue is therefore important in moral education and as well in ethical education. In true dialogue, the needs of the Other are brought into the light. In such dialogue we might usefully include a consideration of the intentions of our actions and reflect upon the effects of them on the quality of teaching and learning. Noddings (2002b) states that this is our way of being in relation' (p. 19).

\section{So how did things work out?}

We worked alongside 30 school staff throughout that day with two appreciative activities - the Show-and-Share activity and the Building Blocks activity. To grasp the 'creative renderings' that surfaced as a consequence of this day we listened when teachers shared their experiences and made field notes of that, collected the teachers' writing on the Building Blocks and, to visually record some of the moments during the day, we documented the process with a digital camera. After the workshop we asked the teachers to reflect on their learning processes and to write this down. They then permitted us to read what they wrote. In the following section we present the two activities and our understanding of these.

\section{The Show-and-Share activity: 'How would I know that every child mattered in your school?'}

To prepare for this day, the staff involved were invited to reflect upon the following: 'Think about and then bring with you, from your school, something that is a great 


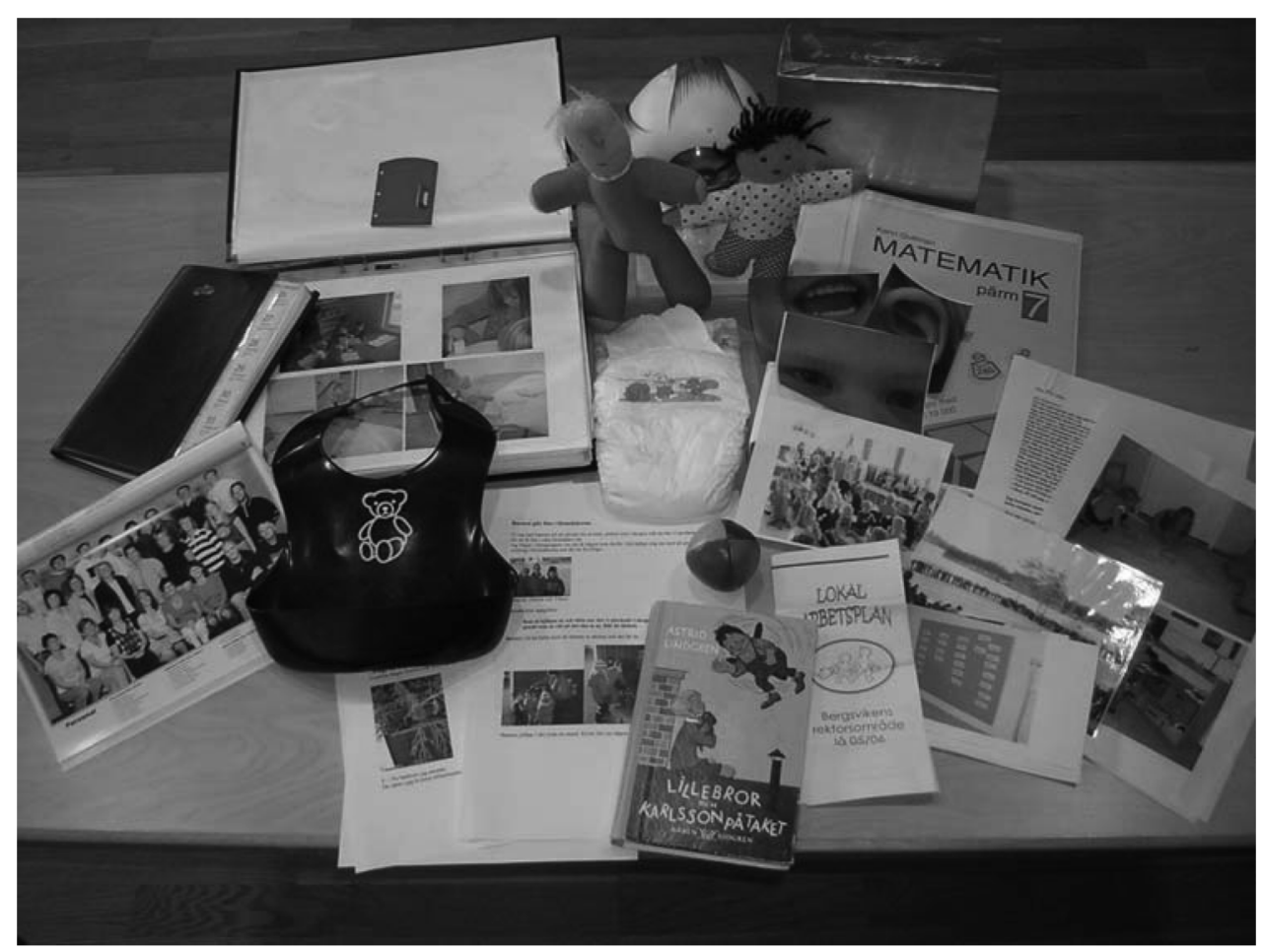

Figure 3. Some symbols of that every child matters in my school

example of the statement, "Every child matters in my school". You will be invited to explain what you have brought along, and why, to others in the group'.

Every teacher brought an artefact to the workshop (see Figure 3). This is what some staff said to others in the group as they responded to the question above. What follows are extracts from our field notes.

Example 1

The cell phone is a tool for me as a secondary teacher to stay connected with children's homes and parents. The connection between me, as the teacher, and the parents is a way of showing that every child matters to me. I feel that it is important to call home both when there are bad news as well as good news. My experience of calling home when there is good news is that the parents are surprised that they get a phone call from the school even though there are no problems with their child. I believe that the parents really appreciate these good news calls.

\section{Example 2}

The golden box is a box where we teachers, in my pre-school, write appreciative words on pieces of paper to each child. All papers are put in the box and at certain occasions we draw pieces of paper from the box and read them out loud for the children. I think that 'the golden box' has been a success among the children. They are really looking forward to the moment when the box is opened and they have the opportunity to hear these appreciative words about themselves or their mates. 


\section{Example 3}

I show my own hands as tools for making physical contact with the children in my primary school. I mean that a touch from the hand or a handshake can be a way of showing that every child matters in school.

\section{Example 4}

I have brought a plastic model of an eye and it's a symbol for seeing all my children in my primary school. I think I have many opportunities to use my body and my senses as tools for demonstrating that every child matters in their school.

\section{Example 5}

Now I want to sing a song for you today. I want to show that song and music can be used as tools and evidence for the thought that every child matters. When I sing a song where all children's names are sung out load, there is a way of seeing the individual child.

\section{Example 6}

I have brought a diaper to this session. When we change diapers at my pre-school, we try to make that moment with every child to a special moment. We take time to talk to and see the child. We want this moment to be a learning moment for the child. Together with the children we talk about different body parts, what has happened during the day or we sing a song.

\section{Example 7}

This is a bib and it symbolizes the meals for me. I feel that the meals are important moments in the daily activities in a pre-school. I, and the other teachers in my pre-school, are consciously making these moments into chances for talking to the children and seeing every child. We have this opportunity because one or two teachers are sitting and eating together with a quite few number of children at the same table.

\section{Example 8}

A plastic door means for me as a pre-school teacher a warm welcome of every child and their parents already at the doorway in the foyer. This means that it is important with a friendly behaviour, which I think makes the children safer to enter the pre-school and more prepared to participate in the activities during the day.

\section{Example 9}

In our pre-school we make portfolios on every child. The documents in the portfolio can, for example, be drawings created by the children and pictures showing the children in different kinds of activities. The overall purpose of the portfolio is to document the learning of each child and their reflections on their learning processes. I think that this method appreciates each child's ability.

\section{Example 10}

A book of short stories, created by my secondary children, is what I bring along today. The children wrote this book together. I think that this book visualizes and mediates the voices of the children in an explicit way. I feel that I have the opportunity to get to know their thoughts and feelings. The fact that they have to write together enables them to meet and take a position on each others' thoughts, feelings and values. This joint production indicates that every child matters to me.

\section{Our understanding of the Show-and-Share activity}

Through a reflection on our facilitation of the workshop and an analysis of the data gathered, a number of 'learning themes' emerged. They are presented below. 
The importance of creating and sustaining contact with children and their parents. Teachers from different schools, from pre-school to secondary school, showed artefacts which aimed to create and/or sustain contact with children and their homes. Examples of this are the cell phone and the plastic door. The cell phone was important for the teacher to inform the parents about their child's situation in school. We think that she stresses something important when she said that the phone is also used for good news calls, not always when something is wrong. This appreciation is, as we see it, a basis for the building of ethical places and spaces, because it pushes development further. 'Good news stories are used to craft possibility propositions that bridge the best of what is, with collective aspiration of what might be' (Cooperrider \& Whitney, 2005, p. 29). Here we see that good news stories can be a bridge in the development from now to the future. The 'Welcome' in the foyer, which the plastic door represents, creates a positive contact with both children and their parents. It signifies an invitation. The teachers are inviting children and parents to be a part of the learning and development processes that hopefully are taking place in the pre-school. This invitation also means an invitation to a You-relation as Buber (1997) puts it. To be in a relation we must treat each other as a You (Thou) and not as an It, an object. We think that is what the teachers at this particular school are trying to achieve in their interactions with children and parents.

The use of physical contact with children. By showing symbols like the hand, eye and ear, the teachers seem to be stressing the importance of appreciative physical contact and gentle touch. Teachers of very young children can sensitively use closeness and physical contact as a way of showing that every child matters. The preschool teachers who were talking about daily activities, such as diaper changes and meals, regard these as special moments of learning. According to Merleau-Ponty (1996) learning is moulded by the experiences we as human beings are undergoing in the world, and these experiences are above all incorporated through our body. We view the world through our eyes, we listen through our ears, we incorporate different experiences of taste through our mouth, we grasp, caress and feel things or other people through our hands. Thus, it is through our body that we have experiences in the world, which in turn are prerequisites for learning (Alerby, 2007). Appropriate physical or bodily contact between teacher and child, guided by the teachers' professional code of conduct, of the teachers' union in Sweden (Lärarnas Riksförbund \& Lärarförbundet, 2001), is an important way of expressing this aspect of an ethic of care.

To appreciate, see and notice every child. All artefacts suggest, in some way, that every child matters. But arguably some of the artefacts are more explicit in showing this. We have for example the golden box, song and music, portfolio and a book of short stories. The aim of these artefacts is to appreciate the child and make the appreciation visual. It also emphasizes the gifts and talents of each child. According to 
Dahlberg et al. (1999) pedagogical documentation in children's portfolios shows their achievements. When children work together for example in creating the storybook, there is an opportunity of learning from each other, which creates opportunities for appreciating each other. Noddings (2002a) writes: 'students should be encouraged to work together, to help one other-not just to improve academic performance, but to gain competence in caring' (p. 20).

\section{The Building Blocks activity: 'How would I know that every member of staff mattered in your school?'}

Each member of staff was provided with a card template in the form of a cube. They were asked to reflect on the unfinished statement 'You would know that every member of staff matters in my school because ...' and complete it, writing their personal thoughts on one face of the cube. In groups, staff were then invited to discover and discuss any differences, similarities or connections between their individual cubes. Group discussions were represented by the physical arrangement of cubes on each table (see Figure 1). Some cubes were aligned horizontally with others. Some placed on top of others. Here are examples of what some teachers wrote on their building bricks (see Figure 4).

Every one is important in the organization we have right now, we complement each other and see the children together.

We need each other in our work.

All voices of the pedagogues are heard.

That all are striving towards the same goal, for example reading. Every one is needed.

We are all different and unique and important.

I get treated with respect and I myself meet my colleagues with respect.

The evidence is my own feeling that I can trust all colleagues in the working team. A positive encouraging atmosphere makes every body enjoy the work.

\section{Our understanding of the Building Blocks activity}

Through our facilitation of the workshop and our post-event reflections, some additional 'learning themes' emerged. These are presented below.

The importance of the positive response. The teachers wrote that positive responses and how they treated each other in their daily work was evidence that every teacher mattered in their schools. This is suggestive that these things are very important to the development in an ethical school. Lévinas (1993) suggests, as we pointed out earlier, that from the moment I see the Other, in that moment I am responsible for that person. He also stresses that Saying (how we say something) is sometimes more 


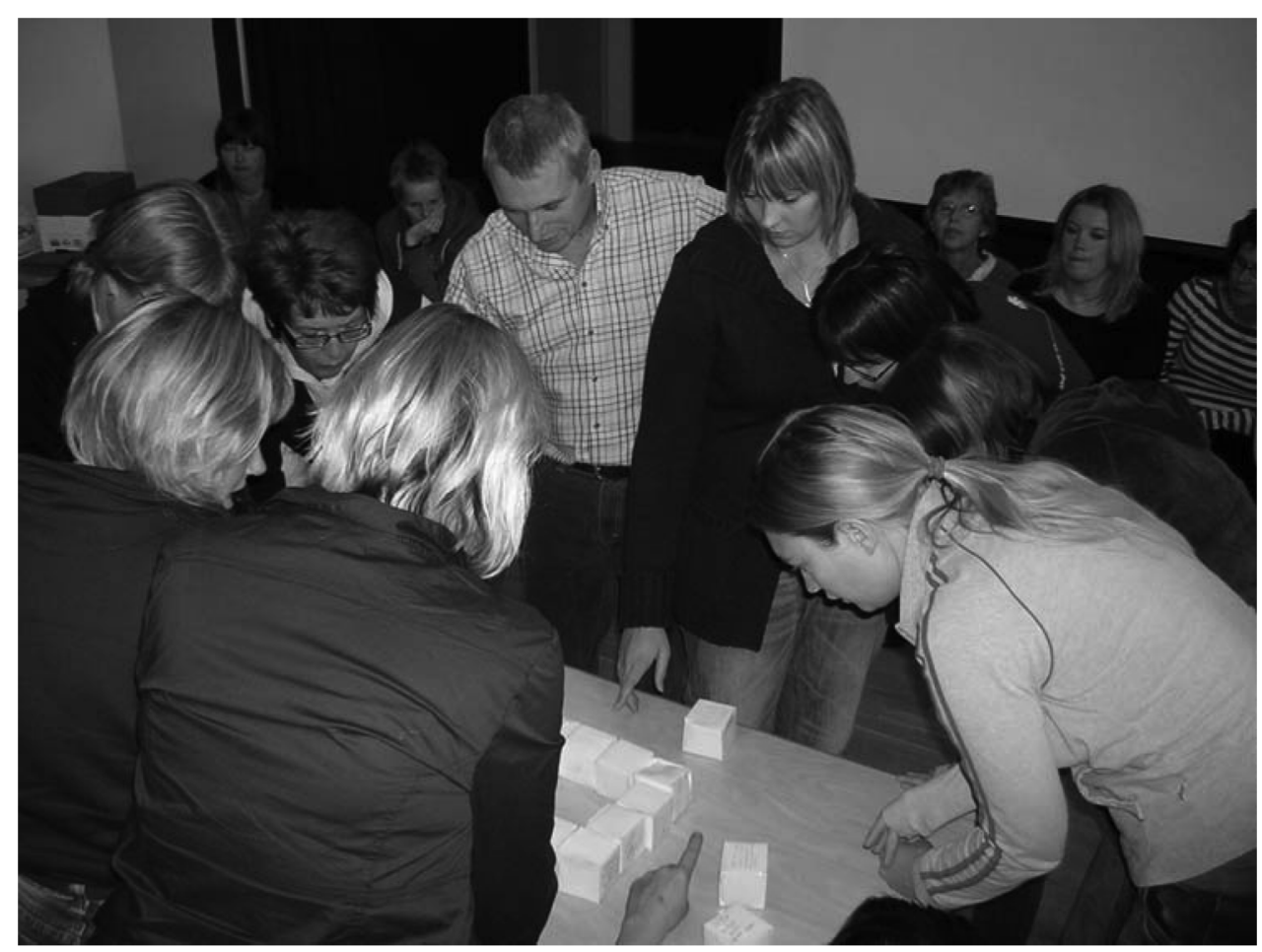

Figure 4. Using personally constructed building blocks to develop shared understanding

important than the Said (the content of the message). The content and form of communication are therefore both important.

The importance of teamwork. Working together in teams or groups is highlighted on the teachers' cubes. This suggests that teamwork is an essential brick in the building of an ethical school. Without each other we cannot build a shared community where both children and teachers matter. When working together a 'collective wisdom' can be reached (Cooperrider \& Whitney, 2005, p. 10). This wisdom can facilitate opportunities for creating synergy among the staff and enables change.

Valuing individuality. For the teachers, who participated in this workshop, it is important that every voice can be heard in a school. In organizational change, Whitney and Trosten-Bloom (2003) encourage people, not only to discover their gifts and strengths but also the equality of voice. In the ethical school we could argue that everyone ought to have the opportunity to speak about their visions of positive change. School leaders play an important role in this work. They have the opportunity to listen to the creative ideas and visions of their staff and then it is 
their job to 'plant the seed and nurture the best in others' (Cooperrider \& Whitney, 2005, p. 45).

\section{So what did some of the staff learn from participating in the workshop?}

We invited staff who attended the workshop to write some short reflective notes in response to the statement, 'The most significant thing I learnt today was ...'. Some examples of what they wrote follow.

A day like this gives you strength to go on, it spreads like rings on the water. ... It was a way of reflecting on and appreciating the positive things we do.

The workshop made us show each other that we work very well in many places in this southern school area, in order to see every child. It gave me a satisfaction and a feeling that I can be proud of my work.

I want to begin to thank for a very inspiring day! ... This is the thing I think is so inspiring: to be forced to reflect on something I think is obvious and show my reflections in words, orally or in writing.

It is so amazingly interesting to hear the many different stories ... I realize again that we seldom listen to each other between the 'stages'. I am above all struck by how serious every/ many of the pre-school teachers are. What work they do! What projects they work with!

I wish that we later would have done the same thing with all the staff in my school, but we haven't done that.

It was a very warm feeling to be part of it and I also experienced that everybody felt important and appreciated.

In long term view these and similar exercises make that our thoughts change direction. Our ways of thinking in even more ethical directions develop slowly.

Experience without reflection doesn't lead to development, but we stand still on the same development level. Do we dare to reflect on the question: Do we have 20 years of experience or 1 year of experience 20 times?

It is important for the own development to reflect, question, draw conclusions, try and evaluate. ... I have chosen to turn the heading 'Every child matters' to 'Which teacher matters to you?' Would we dare to ask such a question to our students and children? Would we get the answer we wish? I think that if we would take the result from a VCR on our selves when we work and the answers to 'Which teacher matters to you?' we would have many suggestions of how we can develop as pedagogues.

I know that what I do is good but I haven't fully taken the step and reflected on why I do things in a certain way and what signals it sends to the children. It is often small things I take for granted but which I should think more about.

\section{So what did we learn from facilitating this kind of workshop?}

In this part of our reflective account we wish to place on the page our shared reflections and learning from the workshop, as an example of how we might support the building of ethical spaces and places. 
For us, the workshop embraced many of the characteristics of participatory and appreciative action research or PAAR (Ghaye, 2007). A popular conception of earlier notions of PAAR and often called participatory action research (PAR) is that it is a convergence and coalescence of theoretical and practical traditions from diverse fields of human service endeavour like school work, health care, social work, organizational and community development and so on. This is often attributed to two things (Kemmis, 2006). First, due to the revitalization of communitarian politics and its association with participatory development, empowered participation and political activism (Botes \& van Rensburg, 2000; Butcher et al., 2000; Lenneiye, 2000). Second, due to the apparent failure of some positivistic research and its assumption of universal applicability in new social, cultural and economic contexts. In our work in this municipality, we feel we are developing PAR into PAAR. Not only is it actionoriented, cooperative research (Heron \& Reason, 2001) in which all those involved discover and address common successes, needs and concerns. It is also appreciative in the sense that it seeks to build and sustain 'enabling ethical relationships' between all those involved in order to create more possible and improved futures. It is different from other kinds of action-oriented research in two basic ways. First because of the central role that school staff (and pupils) themselves, play in it. Secondly because any concerted engagement in change-producing activity requires conscious, systematic, rigorous and public reflection-on-action from those involved. PAAR is therefore a kind of social practice and often referred to as research of the people, by the people and for the people (Park, 1997). It has the potential to build learning communities and heighten critical consciousness. It also enables staff, children, parents and significant others in the school's community, to reframe the given situation, and in so doing, to recognize the positive possibilities, for improving the quality of learning and teaching there.

So two of the defining characteristics of PAAR are that it is participatory and appreciative (see Figure 5). This participatory characteristic (Jacobs, 2006) requires all involved to be reflective, to be explicit about the perspective from which knowledge is created and to see democratic peer-relationships as an ethical and political form of inquiry, that serves the practical ethos of action research. The ethical and political dimensions of PAAR affirms the right and ability, of all those involved in a place called school, to have a say in decisions that affect the quality of school life (learning and teaching) and which claim to generate knowledge about them (Magnusson \& Hanson, 2003). PAAR therefore positively embraces the connection between the way power is used and circulates amongst groups, on the one hand, and the way knowledge is generated and used on the other (Thatchenkery \& Chowdry, 2007). The appreciative characteristic is critical because of the way some forms of action research maintain a problem-oriented view of the world. In so doing, they diminish the capacity of all involved to produce innovative theory capable of inspiring the imagination, increasing participant commitment and generating strengths-based dialogues required for sustainable improvements in learning and teaching. Cooperrider and Whitney (2005) see the appreciative dimension as a way of achieving this. 


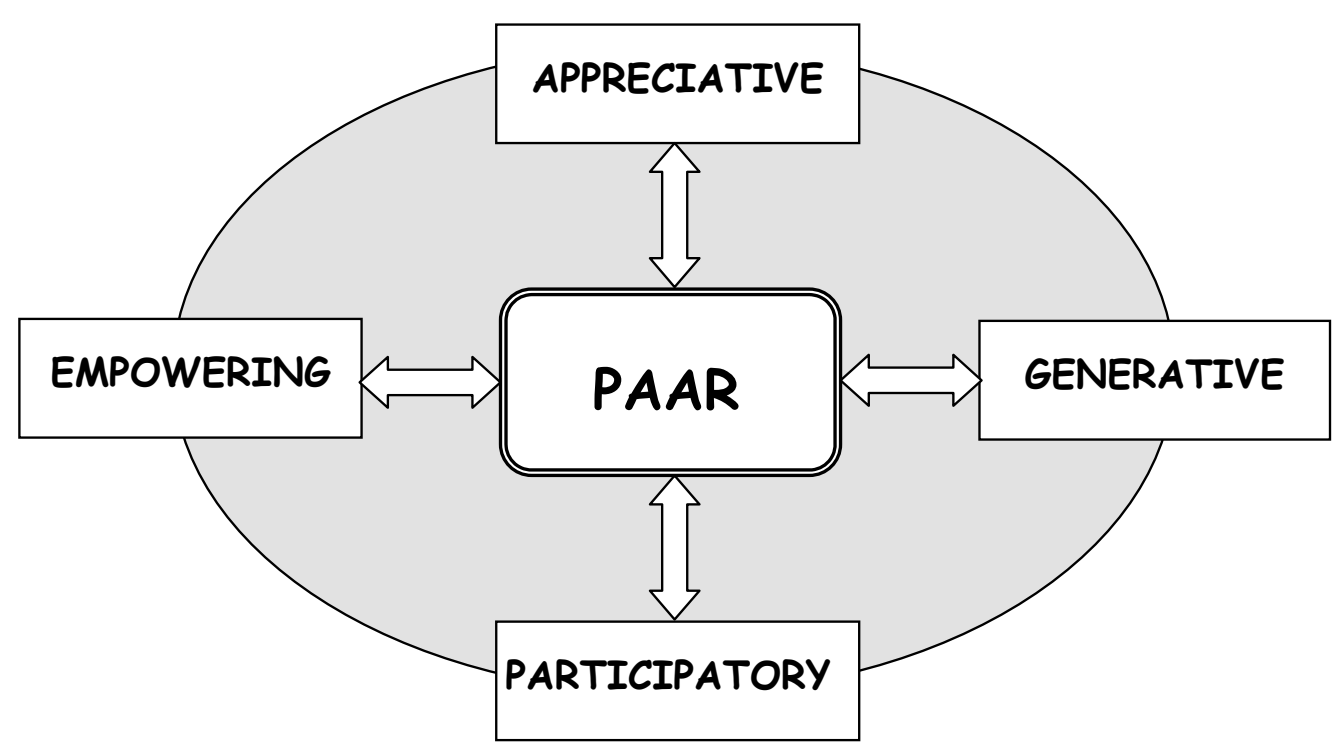

Figure 5. The characteristics of participatory and appreciative action research. From Ghaye, 2007

PAAR has two further characteristics (see Figure 5). It also has the potential to be empowering and generative (Applelbaum et al., 1999; Duvall, 1999; Stainer \& Stainer, 2000; Renblad, 2003; Wikström, 2005; Melander-Wikman et al., 2006). We believe our workshop to have been underpinned by the notion of empowered participation (Fung, 2006) and its associated process of deliberative democracy (Thomson \& Gutmann, 2004). Together these demonstrate a commitment to positively engage with, and provide equal opportunities for, all staff involved to participate directly in discussions and actions about building ethical places and spaces. We believe this kind of workshop to be (potentially) empowering because decisions, generated by the processes of PAAR, determine the actions of all those charged with the responsibility of improving learning and teaching in school. The process of deliberative democracy is a crucial component because it affirms the need, for all concerned, to justify the decisions that are made about improving the quality of schoolwork.

We felt that the day could be a positive platform for further work in the schools in the municipality. The teachers expressed that a process of change in building an ethical place and space moves slowly and that they have to take small steps at a time. They stressed that reflection, both together and individually, is an important way for them to make positive changes. Through guided and supported reflection, it is possible to enable teachers to develop themselves and to further develop the notion of an ethical school. Through this process of reflection, the teachers' professional and personal strengths and 'growth points' are highlighted, and it results, hopefully, in a greater awareness of ones self. Noddings (2002b) describes reflection, in connection to caring for all children, in the following terms: 'ethical caring requires reflection and 
self-understanding. We need to understand our own capacities and how we are likely to react in various situations' (p. 15).

In order to use reflection in a learning process, the teachers emphasized that every one must find the way to reflect on their practice, that suits them. It was clear from this one day of appreciative activities that teachers were able to explore and deepen their understandings of the inter-connections between their experiences together and with children, their reflections on them and how this linked with positive change.

\section{We make the road by walking}

We acknowledge Horton and Freire (1990) for the insight, 'we make the road by walking', which is so apposite for us at this moment. As we mentioned at the beginning of this account, the workshop presented here is one thin slice of action, and reflection upon it, from an ongoing and developing collaborative conversation, in northern Sweden. Horton and Freire (ibid.) remind us that the process of education is not imitation, but the creative application of all we know brought into creative dialogue with the historical moment.

Knowledge always is becoming. That is, if the act of knowing has historicity, then today's knowledge about something is not necessarily the same tomorrow. Knowledge is changed to the extent that reality also moves and changes. ... Theory does the same. It's not stabilized, immobilized. (Horton \& Freire, 1990, p. 101)

This idea of knowledge as becoming has close connections to Lévinas' (1969) thoughts that learning from the Other is important in education and also in life. In the workshop we have seen traces of both a will of becoming and change, and also learning from each other in the creative dialogues that occurred that day. As we step forward to try to build ethical places and spaces called school in northern Sweden, we feel these things are important for us to acknowledge. In order to support the further development of schools in the area, we have co-constructed a program for the coming years, where reflection and sharing of knowledge are two important parts. We plan to create a new workshop with staff on ethical dilemmas in the teaching profession and the use of an ethical compass in order to guide decision-making in school. In this workshop we can hopefully use the two activities described in this paper with more staff in the municipality. We have a wish that the following words from Paulo Freire (1998) will guide us through our future work in this school area. 'To live in openness toward others and to have an openended curiosity toward life and its challenges is essential to educational practice' (p. 121).

\section{Acknowledgements}

We would like to thank the staff who participated in this workshop and for the continued support of senior education officers in the Municipality and the Department of Education, Luleå University of Technology, Sweden. 


\section{Consent}

This was not the first time we had met with these teachers and principals. They were all aware that they were part of an ongoing participatory project. Nevertheless we discussed with them that we would like to draw upon the spoken and written words that arose from the workshop in fulfilling our commitment to try to place what was happening, in northern Sweden, in the public domain. Informed consent was given by all participants, to use and cite the creative renderings that surfaced during this workshop and also the written teacher reflections after the workshop.

\section{Notes on contributors}

Ulrika Bergmark is a Ph.D. student at the Department of Education, Luleå University of Technology, Sweden. Her research interest lies within the field of ethical issues in schools, and the focus of her research is exploring how teachers and students experience ethical situations in school, and how teachers and students work together to enhance their learning through an ethical attitude. Through her research Ulrika is connected to a school area in northern Sweden, where work is undertaken to develop ethical pre-schools and schools.

Tony Ghaye achieved the title of Professor in Educare in 2000 after studying and working at the Universities of London and Worcester. He is the first Director of the not-for-profit, international Institute of Reflective Practice-UK and Visiting Professor at Luleå University of Technology. Tony has worked extensively at the interface between health, social care and education in developing and developed countries. He is an organizational strategist who specializes in personal and organizational development. He has chaired national and international conferences and reported to Government Departments in the UK, the Middle East and Australia. He is also currently involved in building reflective teams and organizations that act ethically and with moral courage, and has written, co-written or edited 17 academic texts and published 104 papers.

Eva Alerby is an associate professor in education at the Department of Education, Luleå University of Technology, Sweden. Her main research interests focuses on teaching and learning, and more specifically on people's experiences of different phenomenon within the educational sphere. Currently she is working with a development and research project concerning psychosocial well-being among children and youth in the Arctic. In addition to this she is also interested in research within the field of philosophy of education.

\section{References}

Alerby, E. (2007) 'Knowledge must take a run through the whole body'-some notes concerning the learning of writing as embodied experience, paper presented at the International Conference on Learning, Johannesburg, South Africa, 26-29 June. 
Appelbaum, S., Hébert, D. \& Leroux, S. (1999) Empowerment: power, culture and leadership—a strategy or fad for the millennium?, fournal of workplace Learning: Employee Counselling Today, 11(7), 233-254.

Bergmark, U. \& Alerby, E. (2006) Ethics of care-a dilemma or a challenge in education? Full reviewed paper presented at the Australian Association for Research in Education National Conference (AARE), Adelaide, 27-30 November.

Bergmark, U. \& Alerby, E. (submitted) Developing an ethical school through appreciating practice? Students' lived experience of ethical situations in school, Ethics and Education.

Botes, L. \& van Rensburg, D. (2000) Community participation in development: nine plagues and twelve commandments, Community Development fournal, 35, 41-58.

Buber, M. (1948) Israel and the world: essays in a time of crisis (New York, Schocken Books).

Buber, M. (1972) Between man and man (R. G. Smith, Trans.) (New York, Macmillan). (Original work published 1947.)

Buber, M. (1997) fag och du [Ich und Du] (Margit och Kurt Norell, Trans.) (Ludvika, Dualis förlag $\mathrm{AB}$ ). (Original work published 1923.)

Butcher, K., Dhungana, P., Pant, B. \& Prasi, K. (2000) Partnerships and participation: synthesizing methods to improve the quality of planning and training for primary health care services at district level in Nepal, IDS Bulletin, 31(1), 97-102.

Colnerud, G. \& Granström, K. (2002) Respekt för läraryrket: om lärares yrkesspråk och yrkesetik [Respect for the teaching profession: about teachers' professional language and ethics] (Stockholm, HLS förlag).

Cooperrider, D. \& Whitney, D. (2005) Appreciative inquiry: a positive revolution in change (San Francisco, Berrett-Koehler).

Dahlberg, G., Moss P. \& Pence, A. (1999) Beyond quality in early childhood education and care: postmodern perspectives (London, Falmer Press).

Duvall C. (1999) Developing individual freedom to act. Empowerment in the knowledge organization, Participation and Empowerment: An International fournal, 7, 204-221.

Freire, P. (1970) Pedagogy of the oppressed (New York, Herder \& Herder).

Freire, P. (1998) Pedagogy of freedom. Ethics, democracy and civic courage (Lanham, Rowman \& Littlefield).

Fung, A. (2006) Empowered participation: reinventing urban democracy (Princeton, Princeton University Press).

Ghaye, T. (2007) Building the reflective healthcare organization (Oxford, Blackwell).

Heron, J. \& Reason, P. (2001) The practice of co-operative inquiry: research 'with' rather than 'on' people, in: P. Reason \& H. Bradbury (Eds) Handbook of action research: participative inquiry $\mathcal{E}$ practice (Thousand Oaks, Sage Publications).

Horton, M. \& Freire, P. (1990) We make the road by walking: conversations on educational change (Philadelphia, Temple University Press).

Jacobs, G. (2006) Imagining the flowers, but working the rich and heavy clay: participation and empowerment in action research for health, Educational Action Research, 14(4), $569-581$.

Kahane, A. (2004) Solving tough problems: an open way of talking, listening and creating new realities (San Francisco, Berrett-Koehler).

Kemmis, S. (2006) Participatory action research and the public sphere, Educational Action Research, 14(4), 459-476.

Lenneiye, M. (2000) Testing community empowerment strategies in Zimbabwe: examples from nutrition supplementation and water supply and sanitation programmes, IDS Bulletin, 31(1), 21-29.

Lévinas, E. (1969) Totality and infinity. An essayon exteriority (Pittsburgh, Duquesne University Press).

Lévinas, E. (1989) The Lévinas reader (Oxford, Basil Blackwell).

Lévinas, E. (1993) Etik och oändlighet. Samtal med Philippe Nemo [Éthique et infini] (Stockholm, Brutus Östlings Bokförlag Symposion AB). 
Lärarnas Riksförbund \& Lärarförbundet (2001) Lärares yrkesetik-de yrkesetiska principerna [Teachers' professional ethics - the principles of professional ethics]. Available online at: www.lr.se/lrweb/home.nsf/indexfrmset?readform\&Url=http://www.lr.se/lrweb/home.nsf/ bykey/PKAEL-6YVDVC!OpenDocument (accessed 18 June 2007).

Magnusson, L. \& Hanson, E. J. (2003) Ethical issues arising from a research, technology and development project to support frail older people and their family carers at home, Health and social care in the community, 11(5), 431-439.

Melander-Wikman, A., Jansson, M. \& Ghaye, T. (2006) Reflections on an appreciative approach to empowering elderly people, in home healthcare, Reflective Practice, 7(4), 423-444.

Merleau-Ponty, M. (1996) Phenomenology of perception (London, Routledge).

Noddings, N. (1984) Caring. A feminine approach to ethics and moral education (Berkeley, University of California Press).

Noddings, N. (2002a) Starting at home. Caring and social policy (Berkeley, University of California Press).

Noddings, N. (2002b) Educating moral people. A caring alternative to character education (New York, Teachers College Press).

Park, P. (1997) Participatory research, democracy and community, Practicing Anthropology, 19(3), $8-13$.

Reina, D. \& Reina, M. (2006) Trust and betrayal in the workplace: building effective relationships in your organization (San Francisco, Berrett-Koehler).

Renblad, K. (2003) Empowerment a question about democracy and ethics in everyday life. Doctoral dissertation, Studies in Educational Sciences 68, Stockholm Institute of Education Press.

Stainer A. \& Stainer L. (2000) Empowerment and strategic change-an ethical perspective, Strategic Change, 9, 287-296.

Thatchenkery, T. \& Chowdhry, D. (2007) Appreciative inquiry and knowledge management: a social constructionist perspective (Cheltenham, Edward Elgar Pub).

The Ministry of Education (1994) Läroplaner för det obligatoriska skolväsendet och de frivilliga skolformerna [Curriculum for the compulsory school system and the voluntary types of school] (Stockholm, Ministry of Education).

The Ministry of Education (1998) Läroplaner för det obligatoriska skolväsendet, förskoleklassen och fritidshemmet [Curriculum for the compulsory school system, the pre-school class and the school-age childcare services] (Stockholm, Ministry of Education).

The Ministry of Education (2004) Utbildningsinspektion. Inspektionsrapport fran Skolverket [Evaluation of education] 2004: 43 (Stockholm, Ministry of Education).

Thomson, A. \& Gutmann, D. (2004) Why deliberative democracy? Available online at: http:// press.princeton.edu/chapters/s7869.pdf (accessed 1 July 2007).

Wheatly, M. (2002) Turning to one another: simple conversations to restore hope to the future (San Francisco Berrett-Koehler).

Whitney, D. \& Trosten-Bloom, A. (2003) The power of appreciative inquiry. A practical guide to positive change (San Francisco, Berrett-Koehler).

Wikström, E. (2005) Inflytandets paradoxer. Möjligheter och hinder för självbestämmande och inflytande $i$ hemtjänsten [The Paradoxes of influence. Possibilities and obstacles for autonomy and influence in homecare]. Licentiate thesis in sociology, Department of Social Science, University of Växjö. 